\title{
PENGARUH KOMPETENSI DAN MOTIVASI KERJA TERHADAP KINERJA GURU DENGAN KOMITMEN ORGANISASI SEBAGAI VARIABEL INTERVENING PADA SMK 1 LHOKSUKON
}

\author{
Pipi Ida Sari ${ }^{1)}$, Marbawi ${ }^{2)}$, Murhaban ${ }^{3}$ \\ Program Pascasarjana Ilmu Manajemen Fakultas Ekonomi Dan Bisnis \\ Universitas Malikussaleh Lhokseumawe \\ Correspondence email : pipiidasari@gmail.com
}

\begin{abstract}
This study aims to determine the influence of competence and work motivation through organizational commitment and its impact on teacher performance to the vocational high school North Aceh. The data used is primary data by distributing questionnaires to 74 teacher of the vocational high school North Aceh. Data analysis method used is path analysis and processed with the help of Statistical Package for Social Science (SPSS) application program. The result of the research shows that there is influence of competence and work motivation to organization commitment, and there is also influence of competence, work motivatin and organizational commitment toward teacher performance of the vocational high school North Aceh. Furthermore, the results of the study found that organization commitment variables mediate the absolute (full mediation) relationship of competence and work motivation to the teacher performance to the vocational high school North Aceh.
\end{abstract}

Keywords : Competence, Work Motivation, Organizational Commitment, and Teacher Performance.

\section{PENDAHULUAN}

Perkembangan ilmu manajemen sumber daya manusia pada era digitalisasi yang pesat saat ini telah menciptakan tantangan yang menarik bagi perkembangan ilmu manajemen sumber daya manusia (MSDM), sebagaimana diketahui bahwa imbas pesatnya globalisasi ekonomi dan manajemen telah mendorong peningkatan sumber daya manusia (SDM) yang sangat pesat. Untuk mengetahui kemajuan kinerja SDM, dalam perannya memberi informasi kinerja dalam suatu organisasi, diperlukan adanya penilaian kinerja yang dilakukan secara terus menerus, sehingga dapat mencegah dan menyelesaikan masalah yang terjadi, tujuan sebenarnya mengelola kinerja manusia atap pegawai untuk meningkatkan produktivitas dan efektivitas, serta merancang dan merencanakan kesuksesan bagi setiap pekerja pada sebuah organisasi.

Kinerja guru pada dasarnya merupakan realisasi target oleh sebuah organisasi sekolah, yang mana pencapaiannya melalui pemanfaatan sumber daya yang dimiliki organasisasi pendidikan tersebut, oleh karena itu setiap organisasi pendidikan dalam memanfaatkan sumber dayanya terlebih dahulu menentukan beberapa persyaratan yang akan dicapai ketika mendapatkan sumber dayanya.

Kinerja guru menurut Helfert di dalam Aswan, (2017) adalah sesuatu tampilan keadaan secara utuh pada organisasi pendidikan selama satu periode waktu tertentu dan merupakan hasil atau prestasi guru yang dipengaruhi oleh kegiatan operasional instansi dalam memanfaatkan sumber sumber daya yang dimiliki

terdapat tiga komponen komitmen guru SMK 1 Lhoksukon yaitu: komitmen afektif (affective commitment), yaitu : keterlibatan emosional seseorang pada organisasinya berupa perasan cinta pada organisasi, komitmen kontinyu (continuance commitment), yaitu : persepsi seseorang atas biaya dan resiko dengan meninggalkan organisasi saat ini.

Kompetensi merupakan karakteristik dasar seseorang individu dalam sebuah organisasi dalam mengeluarkan kinerja kerjanya pada suatu pekerjaannya yang dilakukan pada suatu institusi, jadi kompetensi mengandung makna tentang kepribadian yang mendalam dan melekat pada seseorang dengan perilaku yang dapat diprediksi pada berbagai keadaan dan tugas pekerjaannya sepeti kompetensi guru SMK 1 Lhoksukon.

Selain kompetensi, motivasi merupakan indikator yang mampu membuat seorang karyawan lebih puas dalam menjalankan aktivitasnya. Menurut Luthans (2013) motivasi adalah proses sebagai langkah awal seseorang melakukan tindakan akibat kekurangan secara fisik dan psikis atau dengan kata lain adalah suatu dorongan yang 
ditunjukan untuk memenuhi tujuan tertentu. Setiap kegiatan yang dilakukan oleh seseorang didorong oleh suatu kekuasaan dalam diri orang tersebut, kekuatan pendorong inilah yang disebut motivasi.

\section{KePEUSTAKAAN DAN HIPOTESIS}

\section{A. Kompetensi}

menurut Spenser (2013) bahwa kompetensi adalah karakteristik yang ada pada seseorang yang saling berhubungan dengan serangkaian tindakan yang efektif atau kinerja yang tinggi dalam suatu pekerjaan tertentu sesuai dengan keahliannya masing-masing sehingga sukses dalam mencapai tujuan organisasi. Rivai dan Sagala (2014), kompetensi didefinisikan sebagai karakteristik dasar individu yang berhubungan dengan unjuk kerja (kinerja) yang efektif atau kompetensi terbaik (superior) yang beragam dan berbeda dengan pengunjuk kerja lain yang tingkat kompetensinya rata-rata.

\section{B. Motivasi Kera}

Robbins (2015) mengemukakan bahwa motivasi adalah keinginan untuk melakukan sebagai kesediaan untuk mengeluarkan tingkat upaya yang tinggi untuk tujuan-tujuan organisasi, yang dikondisikan oleh kemampuan upaya itu untuk memenuhi suatu kebutuhan individual. Siagian (2015) mengemukakan bahwa dalam kehidupan berorganisasi, termasuk kehidupan berkarya dalam organisasi bisnis, aspek motivasi kerja mutlak mendapat perhatian serius dari para pimpinan.

\section{Komitmen Organisasi}

Menurut Luthans (2013) komitmen organisasi adalah sikap yang merefleksikan loyalitas karyawan pada organisasi dan proses berkelanjutan dimana anggota organisasi mengekresikan perhatiannya terhadap organisasi dan keberhasilan serta kemajuan yang berkelanjutan. Pendapat lain mengatakan komitmen organisasi didefinisikan sebagai kekuatan identifikasi dan keterlibatan individu dengan organisasi. Komitmen yang tinggi dicirikan dengan tiga hal, yaitu : kepercayaan dan penerimaan yang kuat terhadap tujuan dan nilainilai organisasi, kemauan yang kuat untuk bekerja demi organisasi dan keinginan yang kuat untuk tetap menjadi anggota organisasi. Komitmen nampak dalam tiga bentuk sikap yang terpisah tapi saling berhubungan erat, pertama identifikasi dengan misi organisasi, kedua keterlibatan secara psikologis dengan tugas-tugas organisasi dan yang terakhir loyalitas serta keterikatan dengan organisasi (Dessler, 2013).

\section{Kinerja Guru}

Rivai (2010) mengemukakan kinerja merupakan tindakan atau aktivitas dari suatu organisasi pada suatu periode dengan referensi pada sejumlah standar seperti biaya-biaya masa lalu atau yang diproyeksikan, dengan dasar efisiensi, pertanggung jawaban atau akuntabilitas manajemen dan semacamnya. Menurut Hasibuan (2011) dalam Ningrum (2013) pengertian kinerja adalah suatu hasil yang dicapai seseorang dalam melaksakan tugas-tugas yang dibebankan kepadanya yang didasarkan atas kecakapan, pengalaman, dan kesungguhan serta waktu tertentu

Hipotesis merupakan dugaan sementara yang perlu dijawab dalam penelitian dan untuk mencari fakta yang harus dikumpulkan dan dianalisis, hipotesis adalah suatu pertanyaan sementara atau dugaan yang paling memungkinkan yang masih harus dicari kebenarannya, berdasarkan kerangka pemikiran diatas dan penelitian terdahulu yang dilakukan oleh beberapa peneliti maka dapat disusun sebuah hipotesis sebagai berikut :

$\mathrm{H}_{1}$ Diduga terdapat pengaruh positif dan signifikan kompetensi terhadap komitmen organisasi guru SMK 1 Lhoksukon.

$\mathrm{H}_{2}$ Diduga terdapat pengaruh positif dan signifikan motivasi kerja terhadap komitmen organisasi guru SMK 1 Lhoksukon.

$\mathrm{H}_{3}$ Diduga terdapat pengaruh positif dan signifikan kompetensi terhadap kinerja guru SMK 1 Lhoksukon.

$\mathrm{H}_{4}$ Diduga terdapat pengaruh positif dan signifikan motivasi kerja terhadap kinerja guru SMK 1 Lhoksukon.

$\mathrm{H}_{5}$ Diduga terdapat pengaruh positif dan signifikan komitmen organisasi terhadap kinerja guru SMK 1 Lhoksukon. 
$\mathrm{H}_{6}$ Diduga komitmen organisasi memediasi hubungan antara kompetensi dengan kinerja guru SMK 1 Lhoksukon.

$\mathrm{H}_{7}$ Diduga komitmen organisasi memediasi hubungan antara motivasi kerja dengan kinerja guru SMK 1 Lhoksukon.

\section{Kerangka Konseptual}

Kerangka konseptua disusun berdasarkan teori-teori yang dihimpin dan penelitian yang telah dilakukan sebelumnya, berikut ini disampaikan hubungan antar-antar varibel yang digunakan dalam penelitian ini dapat dilihat pada Gambar 1 dibawah ini :

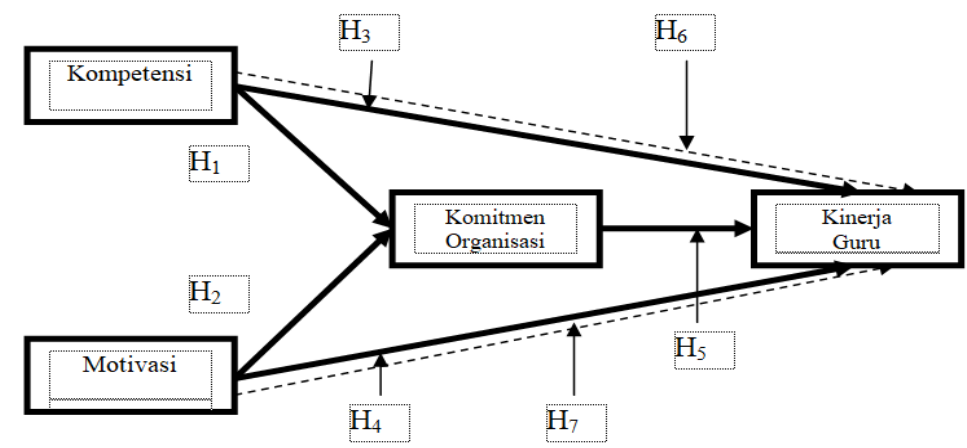

Gambar 1. Kerangka Konseptua

\section{METODELOGI}

\section{A. Lokasi Penelitai Dan Waktu}

Adapun yang menjadi lokasi dalam penelitian ini adalah guru SMK di Kabupaten 1 Lhoksukon, sedangkan yang menjadi objek dalam penelitian ini adalah seluruh seluruh guru SMK Kabupaten 1 Lhoksukon.

\section{B. Jenis Dan Sumber Data}

Dalam penelitian ini jenis dan sumber data yang digunakan adalah data primer berupa kuesioner yang disebut juga data Primer yaitu data yang diperoleh peneliti untuk tujuan khusus dalam menjawab masalah penelitian ( Sugiono, 2015). Data primer dalam peneltian ini adalah data yang didapatkan dari responden guru SMK Negeri 1 Lhoksukon dan SMK Negeri 1 Muara Batu dengan cara menyebakan kuesioner atau daftar pertanyaan.

\section{Populasi}

Menurut Ferdinand (2014) "Populasi adalah wilayah generalisasi yang terdiri atas obyek/subyek yang mempunyai kualitas dan karakteristik tertentu yang ditetapkan oleh peneliti untuk di pelajari dan kemudian ditarik kesimpulanya, jadi guru yang menjadi populasi dalam penelitian ini adalah seluruh guru SMK 1 Lhoksukon berjumlah 74 orang guru.

\section{Sample}

Teknik pengambilan sampel dilakukan dengan metode sensus atau jenuh, teknik penarikan sampel ini dilakukan dengan cara melibatkan seluruh populasi untuk dijadikan sample yaitu sebanyak 74 orang guru SMK Negeri 1 Lhoksukon.

\section{E. Teknik Pengumpulan Data}

Sumber data yang diperlukan kuesioner yaitu data primer, maka teknik pengumpulan data yang digunakan dalam penelitian ini adalah menggunakan angket atau kuesioner adalah suatu alat pengumpulan data yang berupa serangkaian pertanyaan yang diajukan tertulis yang diajukan kepada subyek untuk mendapatkan jawaban secara tertulis dari pada guru SMK Negeri 1 Lhoksukon dan SMK Negeri 1 Muara Batuto. 


\section{F. Analisis Jalur (Path Analysis)}

Pengolahan data dalam penelitian ini dilakukan melalui bantuan komputer dengan program SPSS (Statistical Package for Social Science). Metode yang digunakan untuk mengetahui bagaimana pengaruh antar variabel prediktor (independen/ekogen) dan variabel terikat (dependen/endogen) digunakan analisis model path analisys sebagai berikut :

$\mathrm{Y}_{2}=\rho \mathrm{Y}_{2} \mathrm{X}_{1}+\rho \mathrm{Y}_{2} \mathrm{X}_{2}+\rho \mathrm{Y}_{2} \mathrm{Y}_{1}+\mathrm{e}_{2}$

Analisis data dengan menggunakan bantuan program SPSS terdiri dari dua langkah, pertama adalah analisis substruktur satu dan kedua, untuk analisis substruktur 2 adalah sebagai berikut :

1. $\mathrm{Y}_{1}=\rho \mathrm{Y}_{1} \mathrm{X}_{1}+\rho \mathrm{Y}_{1} \mathrm{X}_{2}+\mathrm{e}_{1} \quad$ (substruktur 1)

2. $Y_{2}=\rho Y_{2} X_{1}+\rho Y_{2} X_{2}+\rho Y_{2} Y_{1}+e_{2}$ ( substruktur 2)

Substruktur 1 dengan persamaan strukturnya :

$\mathrm{Y}_{1}=\rho \mathrm{Y}_{1} \mathrm{X}_{1}+\rho \mathrm{Y}_{1} \mathrm{X}_{2}+\mathrm{e}_{1}$

Keterangan : $\mathrm{Y}=$ Variabel Terikat (dependen)

$\mathrm{Y}_{1}=$ Komitmen Organisasi

$\mathrm{X}_{1}=$ Kompetensi

$\mathrm{X}_{2}=$ Motivasi Kerja

$\mathrm{e}_{1}=$ Error

Substruktur 2 dengan persamaan strukturnya :

$\mathrm{Y}_{2}=\rho \mathrm{Y}_{2} \mathrm{X}_{1}+\rho \mathrm{Y}_{2} \mathrm{X}_{2}+\rho \mathrm{Y}_{2} \mathrm{Y}_{1}+\mathrm{e}_{2}$

Keteragan : $\mathrm{Y}=$ Variabel terikat (dependen)

$\mathrm{Y}_{1}=$ Komitmen Organisasi

$\mathrm{Y}_{2}=$ Kinerja Guru

$\mathrm{X}_{1}=$ Kompetensi

$\mathrm{X}_{2}=$ Motivasi Kerja

$\mathrm{e}_{1}=$ Error

\section{Hasil Peneltian Dan Pembahasan}

Untuk menguji pengaruh atau hubungan antara variabel independen (pendidkan dan pelatihan) dengan variabel dependen (motivasi kerja dan kinerja pegawai) dilakukan dengan menggunakan analisis jalur, analisis jalur merupakan perluasan dari analisis regresi linear berganda, untuk menaksir hubungan kausalitas antar variabel (model causal) yang telah ditetapkan sebelumnya berdasarkan teori.

A. Hasil Penelitian Persamaan Struktur Pertama

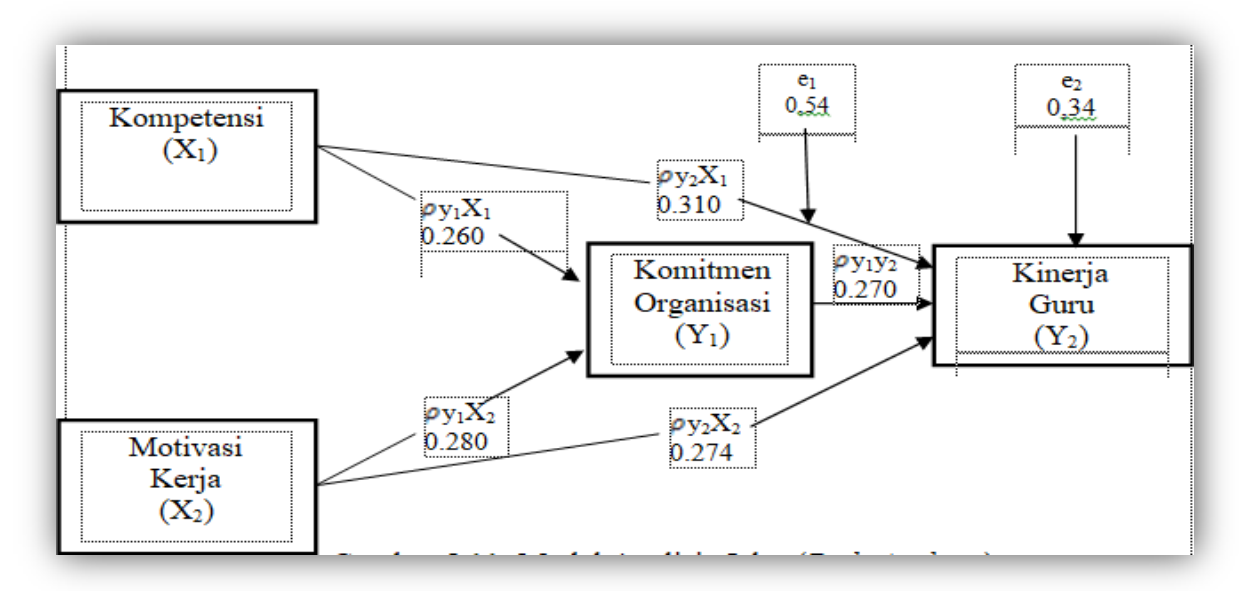

Gambar 2. Model Analisis Jalur 
Uji koefisien determinasi ( $\mathrm{R}_{\text {Square }}$ ) digunakan untuk mengukur seberapa jauh kemampuan model dalam menerangkan variasi variabel dependen untuk melihat pengaruh kompetensi dan motivasi kerja terhadap komitmen organisasi. Berdasarkan estimasi regresi dengan program SPSS dapat dilihat pada Tabel 1 berikut.

Tabel : 1

\begin{tabular}{|c|c|c|c|c|}
\hline Model & $R$ & RSguare & Adjisted R Square & Std, Error of the Estimate \\
\hline & 1. $462^{\mathrm{g}}$ & 0.214 & 0.189 & 3.53254 \\
\hline
\end{tabular}

Berdasarkan Table 5.8 diatas, hasil perhitungan dalam model summary didapatkan hasil besarnya angka koefisien diterminasi $\left(\mathrm{R}^{2}\right)$ adalah adalah 0,462 yang artinya angka tersebut menunjukkan bahwa kompetensi dan motivasi kerja terhadap komitmen organisasi adalah sebesar $46 \%$, sedangkan sisanya $54 \%$ dipengaruhi oleh faktor lain. Dengan demikian, variabelitas komitmen organisasi yang dapat diterangkan dengan mengunakan variabel kompetensi dan motivasi kerja adalah sebesar $46 \%$, sedangkan pengaruh sebesar $54 \%$ disebabkan oleh variabelvariabel di luar model ini seperti kepuasan kerja dan keterlibatan kerja.

Tabel : 2

Hasil Analisis Regresi Simultan ( Uji F)

\begin{tabular}{|c|c|c|c|c|c|}
\hline Model & Sum of Squares & $D f$ & Mean Square & $F$ & Sig. \\
\hline 1 Regression & 213.789 & 2 & 106.895 & 8.566 & $0.001^{\mathrm{s}}$ \\
\hline Residual & 786.165 & 63 & 12.479 & & \\
\hline Total & 999.955 & 65 & & & \\
\hline
\end{tabular}

Hasil perhitungan statistik menunjukkan nilai $\mathrm{Uji}_{\mathrm{F}}$ hitung sebesar 8.599 dengan tingkat signifikansi pada 0,001. Karena probabilitas jauh lebih kecil dari 0,05 maka model regresi dapat digunakan untuk memprediksi komitmen organisai atau dapat dikatakan bahwa variabel kompetensi dan motivasi kerja secara simultan berpengaruh terhadap komitmen organisasi, hal ini disebabkan oleh karena tingkat signifikansi tersebut $<0,05$. Dengan demikian, variabel dalam penelitian ini telah memenuhi persyaratan goodness of fit suatu model path analiysis. Tabel 5.9 di atas dapat disimpulkan bahwa kompetensi dan motivasi kerja secara bersama-sama mempengaruhi komitmen organisasi.

Tabel : 3

\begin{tabular}{|c|c|c|c|c|c|c|}
\hline \multirow{2}{*}{\multicolumn{2}{|c|}{ Model }} & \multicolumn{2}{|c|}{$\begin{array}{c}\text { Unstandardized } \\
\text { Coefficients }\end{array}$} & \multirow{2}{*}{$\begin{array}{c}\text { Standardized } \\
\text { Coefficients } \\
\text { Beta }\end{array}$} & \multirow[t]{2}{*}{$t$} & \multirow[t]{2}{*}{$\mathrm{Sig}$} \\
\hline & & $B$ & Std. Error & & & \\
\hline \multirow[t]{3}{*}{1} & (Constant) & 14.031 & 2.628 & & 5.339 & 0.000 \\
\hline & Kompetensi $\left(\mathrm{X}_{1}\right)$ & 0.250 & 0.121 & 0.260 & 2.063 & 0.043 \\
\hline & Motivasi Kerja $\left(\mathrm{X}_{2}\right)$ & 0.258 & 0.116 & 0.280 & 2.220 & 0.030 \\
\hline
\end{tabular}


1. Pengaruh antara kompetensi terhadap komitmen organisasi

Hasil analisis jalur persaman pertama diperoleh angka $t_{\text {hitung }}$ dalam penelitian sebesar 2.063, taraf signifikansi 0,05 dengan derajat kebebasan (DK) dengan ketentuan $\mathrm{DK}=66-3=63$, dari ketentuan tersebut diperoleh angka $\mathrm{t}_{\text {tabel }}$ sebesar 1,994, berdasarkan hasil perhitungan, diperoleh angka $t_{\text {hitung }}$ penelitian sebesar $2.407>t$ tabel sebesar 1,998 sehingga hipotesis 1 diterima. Artinya, terdapat pengaruh antara kompetensi terhadap komitmen organisasi guru SMK 1 Lhoksukon.

2. Pengaruh antara motivasi kerja dan komitmen organisasi

Hasil analisis jalur persaman pertama diperoleh angka $t_{\text {hitung }}$ dalam penelitian sebesar 2.220 taraf signifikansi 0,05 dengan derajat kebebasan (DK) dengan ketentuan $\mathrm{DK}=66-3=63$, dari ketentuan tersebut diperoleh angka $t_{\text {tabel }}$ sebesar 1,998, berdasarkan hasil perhitungan, diperoleh angka $t_{\text {hitung }}$ penelitian sebesar $2.220>t$ tabel sebesar 1,998 sehingga hipotesi 2 diterima. Artinya, terdapat pengaruh antara motivasi kerja terhadap komitmen organisasi guru SMK 1 Lhoksukon.

B. Hasil Penelitian Persamaan Struktur Kedua

Koefisien determinasi ( $\mathrm{R}_{\text {Square }}$ ) digunakan untuk mengukur seberapa jauh kemampuan model dalam menerangkan variabel dependen untuk hipotesis pengaruh kompetensi, motivasi kerja dan komitmen organisasi terhadap kinerja guru.

Tabel 4

Koefisien Determinasi

Koefisien Determinasi

\begin{tabular}{|c|c|c|c|c}
\hline Model & $R$ & R Square & Adjilsted R Square & Std. Error of the Estimate \\
\hline 1 & $.669 \mathrm{~s}$ & .448 & .421 & 2.13622 \\
\hline a. Predictors: Kompetensi, motivasi kerja \& komitmen organisasi \\
\hline
\end{tabular}

Berdasarkan Tabel 4 perhitungan dalam model summary di dapatkan hasil angka $\mathrm{R}^{2}$ adalah adalah 0,669 yang artinya angka tersebut menunjukkan bahwa variabel kompetensi, motivasi kerja dan komitmen organisasi dapat menjelaskan terhadap kinerja guru adalah sebesar $0.67 \%$, sedangkan sisanya $33 \%$ dijelaskan oleh faktor lain. Dengan demikian, variabilitas kinerja guru yang dapat diterangkan dengan mengunakan variabel kompetensi, motivasi kerja dan komitmen organisasi adalah sebesar $67 \%$, sedangkan sisanya sebesar 33\% dijelaskan oleh variabel-variabel diluar model ini seperti konpensasi dan keterlibata kerja. Pengujian pengaruh variabel bebas secara simultan digunakan uji F. Hasil perhitungan regresi secara simultan dapat dilihat Tabal 5 dibawah :

Tabel 5

Hasil Analisis Reggresi Simultan (Uji F)

\begin{tabular}{l|r|r|r|r|r|}
\hline Model & Sum of Squares & Df & Mean Square & $F$ & Sig. \\
\hline 1 Regression & 229.507 & 3 & 76.502 & 16.764 & .000 s \\
\hline Residual & 282.933 & 62 & 4.563 & & \\
\hline Total & 512.439 & 65 & & & \\
\hline
\end{tabular}

1. Predictors: Kompetensi, Motivasi Kerja \& komitmen organisasi

2. Dependent Variable: Kinerja guru

Hasil perhitungan statiastik menunjukkan nilai $U$ ji $\mathrm{F}_{\text {hitung }}$ sebesar 16.764 dengan tingkat signifikansi pada 0,000. karena probabilitas jauh lebih kecil dari 0,05 maka model regresi dapat digunakan untuk memprediksi kinerja guru atau dapat dikatakan bahwa variabel kompetensi, motivasi kerja dan komitmen organisasi secara simultan berpengaruh terhadap kinerja guru SMK 1 Lhoksukon, di mana taraf signifikansi tersebut $<0,05$ yang berarti bahwa variabel dalam penelitian ini sudah memenuhi syarat pemodelan goodnees of fit dalam model analis jalur.

Tabel 6 


\section{Hasil Analisis Jalur Persamaan 2}

\begin{tabular}{|c|c|c|c|c|c|c|}
\hline \multirow[b]{2}{*}{ Model } & & \multicolumn{2}{|c|}{$\begin{array}{l}\text { Unstandarlized } \\
\text { Coefficients }\end{array}$} & \multirow{2}{*}{$\begin{array}{c}\text { Standardized } \\
\text { Coefficients } \\
\text { Beta }\end{array}$} & \multirow[b]{2}{*}{$t$} & \multirow[b]{2}{*}{ Sig. } \\
\hline & & $B$ & Std. Elror & & & \\
\hline \multirow[t]{4}{*}{1} & (Constant) & 2.638 & 1.915 & & 1.377 & .173 \\
\hline & Kompetensi & 0.213 & 0.076 & 0.310 & 2.816 & .007 \\
\hline & Motivasi Kejja & 0.180 & 0.073 & 0.274 & 2.476 & .016 \\
\hline & Komitmen Organisasi & 0.193 & 0.076 & 0.270 & 2.539 & .014 \\
\hline
\end{tabular}

1. Dependent Variable: Kinerja Guru

1. Pengaruh antara kompetensi terhadap kinerja guru SMK 1 Lhoksukon

Hasil analisis jalur persaman kedua diperoleh angka $t_{\text {hitung }}$ dalam penelitian sebesar 2.816, taraf signifikansi 0,05 dengan derajat kebebasan (DK) dengan ketentuan $\mathrm{DK}=66-3=63$, dari ketentuan tersebut diperoleh angka $\mathrm{t}$ tabel sebesar 1,998, berdasarkan hasil perhitungan, diperoleh angka $t_{\text {hitung }}$ penelitian sebesar $2.816>t$ tabel sebesar 1,998 sehingga hipotesis 3 diterima. Artinya, terdapat pengaruh antara kompetensi terhadap kinerja guru SMK 1 Lhoksukon.

2. Pengaruh antara motivasi kerja terhadap kinerja guru SMK 1 Lhoksukon

Hasil analisis jalur persaman kedua diperoleh angka $t_{\text {hitung }}$ dalam penelitian sebesar 2.476 , taraf signifikansi 0,05 dengan derajat kebebasa $(\mathrm{DK})$ dengan ketentuan $\mathrm{DK}=66-3=63$, dari ketentuan tersebut diperoleh angka $\mathrm{t}$ tabel sebesar 1,998, berdasarkan hasil perhitungan, diperoleh angka $\mathrm{t}_{\text {hitung }}$ penelitian sebesar $2.476>\mathrm{t}_{\text {tabel }}$ sebesar 1,998 sehingga hipotesis 4 diterima. Artinya, terdapat pengaruh antara motivasi kerja terhadap kinerja guru SMK 1 Lhoksukon.

3. Pengaruh komitmen organisasi terhadap kinerja guru SMK 1 Lhoksukon

Hasil analisis jalur kedua diperoleh angka $t_{\text {hitung }}$ dalam penelitian sebesar 2.539 , taraf signifikansi 0,05 dengan derajat kebebasa (DK) dengan ketentuan $\mathrm{DK}=66-3=63$, dari ketentuan tersebut diperoleh angka $\mathrm{t}$ tabel sebesar 1,998, berdasarkan hasil perhitungan, diperoleh angka $t_{\text {hitung }}$ penelitian sebesar $2.539>t_{\text {tabel }}$ sebesar 1,998 sehingga hipotesis 5 diterima. Artinya, terdapat pengaruh antara komitmen organisasi terhadap kinerja guru SMK 1 Lhoksukon.

4. Pengaruh kempetensi terhadap kinerja guru dimediasi komitmen organisasi

Hasil pengujian efek mediasi (intervening) hubungan variabel kompetensi dengan variabel kinerja guru yang dimediasi oleh variabel komitmen organisasi secara full mediation. Untuk mengetahui signifikansi pada jalur c' dapat mengggunakan sobel test an interactive calculation tool for mediation tests yang menghasilkan Sobel test, Aroian test, dan Goodman test. Dalam penelitian ini hasil test yang dipakai untuk melihat test statistic, standar error, dan p-value adalah angka atau nilai dari sobel test.

5. Pengaruh motivasi kerja terhadap kinerja guru dimediasi komitmen organisasi

Hasil pengujian efek mediasi (intervening) hubungan variabel motivasi kerja dengan variabel kinerja guru yang dimediasi oleh variabel komitmen organisasi secara full mediation. Untuk mengetahui signifikansi pada jalur c' dapat mengggunakan sobel test an interactive calculation tool for mediation tests yang menghasilkan Sobel test, Aroian test, dan Goodman test. Dalam penelitian ini hasil test yang dipakai untuk melihat test statistic, standar error, dan pvalue adalah angka atau nilai dari sobel test. 


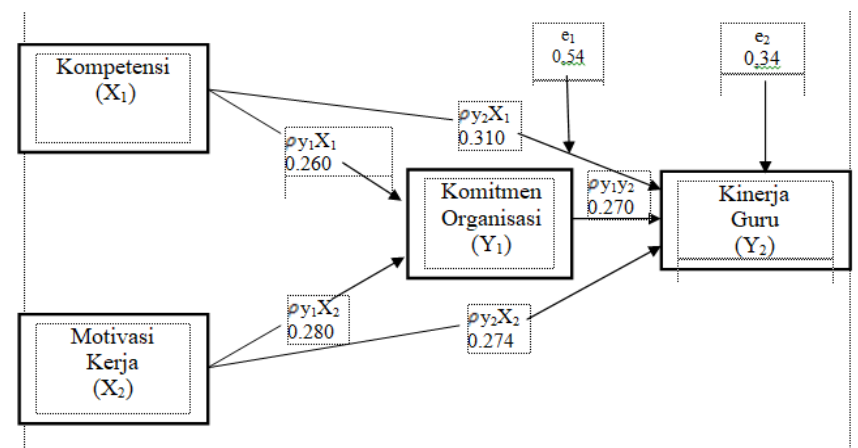

Gambar 2. Model Analisis Jalur (Path Analysis)

Tabel 7 : Outputs Hasil Uji Hipotesi

\begin{tabular}{lllll}
\hline & \multicolumn{1}{c}{ Variabel } & Coeff & Sig & Ket \\
\hline $\mathrm{H}_{1}$ & Kompetensi terhadap komitmen organisasi & 0.043 & Diterima \\
$\mathrm{H}_{2}$ & Motivasi terhadap komitmen organisasi & 0.280 & 0.030 & Diterima \\
$\mathrm{H}_{3}$ & Kompetensi terhadap kinerja guru & 0.310 & 0.007 & Diterima \\
$\mathrm{H}_{4}$ & Motivasi terhadap kinerja guru & 0.274 & 0.016 & Diterima \\
$\mathrm{H}_{5}$ & Komitmen organisasi terhadap kinerja guru & 0.270 & 0.014 & Diterima \\
$\mathrm{H}_{6}$ & Komitmen organisasi memediasi kompetensi terhadap kinerja guru & 0.066 & 0.105 & Diterima \\
$\mathrm{H}_{7}$ & Komitmen memediasi motivasi kerja terhadap kinerja guru & 0.035 & 0.094 & Diterima \\
\hline
\end{tabular}

Sumber : Output SPSS 2019

\section{Pembahasan}

$\mathrm{H}_{1}$ Pengaruh antara kompetensi terhadap komitmen organisasi SMK 1 Lhoksukon

Pengujian secara statistik membuktikan bahwa pada kompetensi guru SMK 1 Lhoksukon di mana dapa mempengaruhi komitmen organisasi hal ini disebabkan kompetensi guru yang diterapakan yang diliki selama ini mam[u menjalan tugas dengan baik, menguasai materi pembelajaran, memiliki ketrampilan dan teknologi pembelajaran dalam menjalan tugasnya di sekolah SMK 1 Lhoksukon.

Hasil penelitian ini didukung Byars dan Rue (2000) bahwa kompetensi seorang pegawai agar dapat melaksanakan jabatan dengan baik, atau juga dapat berarti karakteristik/ciri-ciri seseorang yang mudah dilihat termasuk pengetahuan, keahlian, dan perilaku yang memungkinkan untuk berkinerja. Sebagai konsekuensi kompetensi merujuk pada kemampuan orang untuk memenuhi persyaratan perannya saat ini atau masa yang akan datang, dengan demikian, kompetensi juga bisa untuk meramalkan kinerja dimasa mendatang karena kompetensi merupakan karakteristik yang berkelanjutan yang umumnya tidak bisa hilang (Armstrong, 2005).

$\mathrm{H}_{2} \quad$ Pengaruh antara motivasi kerja terhadap komitmen organisasi SMK 1 Lhoksukon.

Hasil penelitian ini mendukung riset Tania (2013) dimana komitmen organisasional dipandang sebagai suatu orientasi nilai terhadap organisasi yang menunjukkan individu sangat memikirkan dan mengutamakan pekerjaan dan organisasinya. Individu akan berusaha memberikan segala usaha yang dimilikinya dalam rangka membantu organisasi mencapai tujuannya. Fink juga mendefinisikan komitmen organisasional sebagai sikap yang muncul dari proses yang disebut sebagai identifikasi yang terjadi ketika seseorang mempunyai pengalaman dengan sesuatu, seseorang, atau beberapa ide sebagai bentuk perpanjangan dari dirinya (Tania, 2013), komitmen organisasional juga didefinisikan oleh Allen dan Mayer sebagai bentuk kecintaaan karyawan terhadap tempat kerjanya dipengaruhi oleh motivasi kerja.

$\mathrm{H}_{3} \quad$ Pengaruh antara kompetensi terhadap kinerja guru SMK 1 Lhoksukon.

Penelitian ini mendukung hasil penelitian Ningrum (2016) dan Nova (2015) menunjukkan bahwa terdapat pengaruh yang positif dan siginifikan antara kompetensi pedagogik dengan kinerja guru. Persamaan regresi punya arah koefisien positif menunjukkan bahwa hubungan kompetensi pedagogik dan kinerja guru adalah searah, jika 
kompetensi pedagogik semakin tinggi, maka kinerja guru juga semakin tinggi. Hasil penelitian pengaruh kompetensi guru terhadap kinerja guru didukung dalam teori yang dikemukan oleh Saondi (2012) bahwa kinerja seseorang ditentukan oleh kemampuan (kompetensi) untuk melaksanakan pekerjaan. Standar kompetensi yang dimiliki guru telah diatur dalam UndangUndang Nomor 14 Tahun 2005 tentang Standar Nasional Pendidikan bahwa secara tegas menyatakan bahwa ada empat kompetensi yang harus dimiliki guru, salah satunya adalah kompetensi pedagogik.

\section{$\mathrm{H}_{4} \quad$ Pengaruh antara motivasi kerja terhadap kinerja guru SMK 1 Lhoksukon.}

Kinerja pegawai erat kaitannya dengan hasil pekerjaan seseorang dalam organisasi, hasil pekerjaan tersebut dapat menyangkut kualitas, kuantitas, dan ketepatan waktu. Sedangkan kinerja pegawai dipengaruhi oleh kemampuan/ pendidikan, motivasi, lingkungan, disiplin, peraturan, dan yang terpenting adalah dipengaruhi oleh motivasi kerja dalam organisasi tersebut. Penelitian Suzanto (2013) dan Rahman (2016) bahwa hasil penelitiannya motivasi kerja berpengaruh terhadap kinerja pegawai sehingga disimpulkan pengaruh motivasi kerja secara parsial memberikan kontribusi terhadap kinerja aparatur dalam sebuah organisasi. Hal itu menunjukkan bahwa motivasi kerja berpengaruh terhadap kinerja aparat, sehingga dapat disimpulkan motivasi kerja berpengaruh positif dan signifikan terhadap kinerja pegawai.

Dalam penelitian Nova (2015) hubungan motivasi dengan kinerja dalam organisasi untuk pengembangan karyawan berbasis kompetensi dan motivasi kerja merupakan salah satu upaya dapat meningkatkan kinerja, karena pengembangan karyawan berbasis kompetensi dan mendorong motivasi kerja merupakan wujud perhatian dan pengakuan perusahaan atau pimpinan kepada karyawan yang menunjukan kemampuan kerja, kerajinan, dan kepatuhan serta disiplin kerja (Perpusunpas, 2009).

$\mathrm{H}_{5} \quad$ Pengaruh antara kompetensi terhadap kinerja guru SMK 1 Lhoksukon.

Komitmen organisasional menunjukkan suatu daya manusia dari seseorang dalam mengidentifikasikan keterlibatannya dalam suatu bagian organisasi (Mowday, et al. dalam Vandenberg, dalam Trisnaningsih (2007), penelitian ini mendukung penelitian komitmen organisasional dibangun atas dasar kepercayaan pekerja atas nilai-nilai organisasi, kerelaan pekerja membantu mewujudkan tujuan organisasi dan loyalitas untuk tetap menjadi anggota organisasi, oleh karena itu, komitmen organisasi akan menimbulkan rasa ikut memiliki (sense of belonging) bagi pekerja terhadap organisasi.

Jika pekerja merasa jiwanya terikat dengan nilai-nilai organisasional yang ada maka dia akan merasa senang dalam bekerja, sehingga kinerjanya dapat meningkat. Meyer et al. (Suparyadi, 2015) menguji hubungan antara kinerja manajer tingkat atas dengan komitmen affective dan komitmen continuance pada perusahaan jasa makanan. Hasil penelitiannya menyatakan bahwa komitmen affective berkorelasi secara positif dengan kinerja, sedangkan komitmen continuance berkorelasi secara negatif dengan kinerja. Somers dan Birnbaum (1998) mengemukakan bahwa komitmen organisasional (affective dan continuance) tidak berpengaruh terhadap kinerja.

\section{Kesimpulan}

Berdasarkan tujuah penelitian yang telah diuraikan sebelumnya, maka dapat dikemukakan beberapa kesimpulan penelitian sebagai berikut :

1. Variabel kompetensi berpengaruh positif dan signifikan terhadap komitmen organisasi guru SMK 1 Lhoksukon, hal ini bermakna jika kompetensi dpat ditingkatkan maka komitmen organisasi akan meningkat.

2. Variabel motivasi kerja berpengaruh positif dan signifikan terhadap komitmen organisasi, hal ini bermakna jika motivasi kerja meningkat maka komitmen organisasi akan meningkat.

3. Variabel kompetensi berpengaruh positif dan signifikan terhadap kinerja guru SMK 1 Lhoksukon, hal ini bermakna jika kompetensi guru meningkat komitmennya akan meningkat juga.

4. Variabel motivasi kerja berpengaruh positif dan signifikan terhadap komitmen organisasi, hal ini bermakna jika motivasi kerja meningkat maka kinerja guru akan meningkat.

5. Variabel komitmen organisasi berpengaruh positif dan signifikan terhadap kinerja guru SMP 1 Lhoksukon, hal ini bermakna jika komitmen organisasi baik dan meningkat maka kinerja guru akan meningkat juga.

6. Variabel komitmen organisasi memediasi secara penuh hubungan antara kompetensi terhadap kinerja guru SMK 1 Lhoksukon.

7. Variabel komitmen organisasi memediasi secara penuh hubungan antara motivasi kerja dengan kinerja guru SMK 1 


\section{Lhoksukon.}

\section{SARAN-SARAN}

1. Diharapkan kepala sekolah SMK 1 Lhoksukon dan unsur manajemen agar meningkatkan kualitas pembelajaran, ketrampilan para guru dalam rangka meningkatkan komitmen dan kinerja guru SMK 1 Lhoksukon.

2. Kepala sekolah perlu terus membina hubungan kerjasama antar para guru melaui komunikasi yang efektif, oleh karena peran pimpinan instansi untuk menjaga keharmonisan para guru sangat dibutuhkan guna meningkatkan komitmen dan kinerja organisasi SMK 1 Lhoksukon.

3. Setiap guru pada SMK 1 Lhoksukon agar meningkatkan kompetensi dan motivasinya dalam rangka peningkatan kualitas proses belajar mengajar dan meningkatkan mutu lulusan siswa dan peningkatan kinerja organisasi SMK 1 Lhoksukon.

\section{Kepustakaan}

Anwar Prabu, Mangkunegara (2007). Manajemen Sumber Daya Perusahaan, Bandung; PT.Remaja Rosda Karya.

Alfian, Mohd. Riza (2015). Pengaruh Pendidikan, Pelatihan dan lingkungan Kerja Terhadap Kinerja Pegawai Pada Dinas Kehutanan Dan Perkebunan Kabupaten Bireuen Dengan Kepuasan Kerja Sebagai Variabel Intervening, Tesis Program Pascasarjana Ilmu Manajemen (PPIM) Unimal, 1 Lhoksukon

Ardara, Mujiati, Utama (2012), Manajemen sumber daya manusia. Cetakan pertama. Penerbit PT.Graha Ilmu Yogyakarta.

Arikunto, S. (2006). Prosedur Penelitian : Suatu Pendekatan Praktik, Edisi VI, Penerbit PT. Rineka Cipta, Jakarta.

Bakhtiar (2017). Pengaruh Komunikasi, Kompetensi Dan Beban Kerja Terhadap Komitmen Organisasi Dan Dampaknya Terhadap Kinerja Guru SMAN Pada UPDP Samudra dan Syamtalira Bayu, Tesis PPIM Universitas Malikussaleh.

Bangun, Wilson. (2012) manajemen Sumber Daya Manusia. PT Erlangga, Jakarta.

Bernadin H. John and Joyce E.A. Russel (1993). Human Resources Management An. Expriental Approach. New York; Mc Graw. Hill.

Baron and Kenny (1986), Asymptotic confidence intervals for indirect effect in S.Leinhard (Ed).

Bangun, Wilson. (2012). Manajemen Sumber Daya Manusia, Jakarta : Erlangga.

Bernadin, H. John and Joyce. A. Russell, (1993). Human Resource Management : An Experiential Approach, Boston : Mc.Graw Hill.

Brahmasari, Suprayetno, Agus (2008). Pengaruh motivasi kerja dan budaya organisasi terhadap kepuasan kerja karyawan serta dampaknya pada kinerja perusahaan ( studi kasus pada PT. Pei hai International Wiratama Indonesia) Jurnal manajemen dan kewirausahaan, vol No 2, September $2008: 124-135$

Byars, Lloyd L, dan Rue, Leslie W, 2000, Human Resource Management, Boston: McGraw-Hill,

E.Sikula. (2012). Personel Administration And Human $\quad$ Resources Management. New York. A. Wiley Trans edition, by Jhon Wiley \& Sons.Inc

Anwar Prabu, Mangkunegara (2007). Manajemen Sumber Daya Perusahaan, Bandung; PT.Remaja Rosda Karya.

Alfian, Mohd. Riza (2015). Pengaruh Pendidikan, Pelatihan dan lingkungan Kerja Terhadap Kinerja Pegawai Pada Dinas Kehutanan Dan Perkebunan Kabupaten Bireuen Dengan Kepuasan Kerja Sebagai Variabel Intervening, Tesis Program Pascasarjana Ilmu Manajemen (PPIM) Unimal, 1 Lhoksukon

Ardara, Mujiati, Utama (2012), Manajemen sumber daya manusia. Cetakan pertama. Penerbit PT.Graha Ilmu Yogyakarta.

Arikunto, S. (2006). Prosedur Penelitian : Suatu Pendekatan Praktik, Edisi VI, Penerbit PT. Rineka Cipta, Jakarta.

Bakhtiar (2017). Pengaruh Komunikasi, Kompetensi Dan Beban Kerja Terhadap Komitmen Organisasi Dan Dampaknya Terhadap Kinerja Guru SMAN Pada UPDP Samudra dan Syamtalira Bayu, Tesis PPIM Universitas Malikussaleh.

Bangun, Wilson. (2012) manajemen Sumber Daya Manusia. PT Erlangga, Jakarta.

Bernadin H. John and Joyce E.A. Russel (1993). Human Resources Management An. Expriental Approach. New York; Mc Graw. Hill.

Baron and Kenny (1986), Asymptotic confidence intervals for indirect effect in S.Leinhard (Ed).

Bangun, Wilson. (2012). Manajemen Sumber Daya Manusia, Jakarta : Erlangga.

Bernadin, H. John and Joyce. A. Russell, (1993). Human Resource Management : An Experiential Approach, Boston : Mc.Graw Hill. 
Brahmasari, Suprayetno, Agus (2008). Pengaruh motivasi kerja dan budaya organisasi terhadap kepuasan kerja karyawan serta dampaknya pada kinerja perusahaan ( studi kasus pada PT. Pei hai International Wiratama Indonesia) Jurnal manajemen dan kewirausahaan, vol No 2, September $2008: 124-135$

Byars, Lloyd L, dan Rue, Leslie W, 2000, Human Resource Management, Boston: McGraw-Hill,

E.Sikula. (2012). Personel Administration And Human

Resources Management. New York. A. Wiley Trans edition, by Jhon Wiley \& Sons.Inc 